Abstractacta Iranica

Revue bibliographique pour le domaine irano-aryen

Volume 23 | 2002

Comptes rendus des publications de $\mathbf{2 0 0 0}$

\title{
« Do bāl-e ḥekmat ». Našr-e Dāneš, 17, 3 (1379/2000), pp. 67-68.
}

\section{Charles-Henri de Fouchécour}

\section{(2) OpenEdition}

1 Journals

\section{Édition électronique}

URL : http://journals.openedition.org/abstractairanica/35597

DOI : 10.4000/abstractairanica.35597

ISSN : 1961-960X

Éditeur :

CNRS (UMR 7528 Mondes iraniens et indiens), Éditions de l'IFRI

\section{Édition imprimée}

Date de publication : 15 mai 2002

ISSN : 0240-8910

\section{Référence électronique}

Charles-Henri de Fouchécour, « «Do bāl-e hekmat ». Našr-e Dāneš, 17, 3 (1379/2000), pp. 67-68. », Abstracta Iranica [En ligne], Volume 23 | 2002, document 221, mis en ligne le 08 février 2010, consulté le 25 septembre 2020. URL : http://journals.openedition.org/abstractairanica/35597 ; DOI : https:// doi.org/10.4000/abstractairanica.35597

Ce document a été généré automatiquement le 25 septembre 2020.

Tous droits réservés 


\section{« Do bāl-e hekmat ». Našr-e Dāneš , 17, 3 (1379/2000), pp. 67-68.}

\section{Charles-Henri de Fouchécour}

Court mais suggestif et très utile article, en complément au travail prometteur de Shokoufeh Taghi, The Two Wings of Wisdom. Mysticism and Philosophy in the "Risālat Uț-t air » of Ibn Sina (Uppsala, Studia Iranica Upsaliensia, 2000), thèse dirigée par Bo Utas.

\section{INDEX}

Thèmes : 8. Soufisme

\section{AUTEURS}

CHARLES-HENRI DE FOUCHÉCOUR

Sorbonne Nouvelle - Paris III 